reported to cause muscle fibre necrosis, ${ }^{2}$ and magnesium was not given to our patient during his fast. Likewise vitamin $\mathrm{E}$ deficiency is described as a cause of obscure proximal myopathy ${ }^{3}$ and the serum concentration of this vitamin fell just below normal $(14 \mu \mathrm{mol} / 1$; normal range $16 \cdot 3-30 \cdot 7 \mu \mathrm{mol} / \mathrm{l}$ ) by the end of the fast. The fact that a clinically evident myopathy did not appear until seven weeks after the fast was broken might suggest that its appearance was facilitated by the fluid retention which occurs in the early weeks of refeeding and might point to electrolyte shifts in the production of the syndrome.

Whatever its cause, clinical myopathy as the sequel to prolonged fasting appears to be a rare and self-limiting condition. Nevertheless, in view of its association with near-fatal cardiac arrhythmias in our patient it seems worth while to make regular measurements of voluntary muscle function during therapeutic starvation, to use evidence of muscle dysfunction as an indication to terminate the fast, and to monitor cardiac function in these patients with great care during the early weeks of refeeding.

We thank Dr G S Fell of the department of biochemistry, Glasgow Royal Infirmary, for measurements of vitamin $E$ levels.

${ }^{1}$ Garnett ES, Barnard DL, Ford J, Goodbody RA, Wodehouse MA. Gross fragmentation of cardiac myofibrils after therapeutic starvation for obesity. Lancet $1969 ; \mathrm{i}: 914-6$.

${ }^{2}$ Kakulas BA. Experimental myopathies. In: Walton JN, ed. Disorders of voluntary muscle. Edinburgh: Churchill Livingstone, 1974: 462-87.

${ }^{3}$ Bauman MB, DiMase JD, Oski F, Senior JR. Brown bowel and skeletal myopathy associated with vitamin E depletion in pancreatic insufficiency. Gastroenterology 1968;54:93-100.

\title{
Hydatidiform mole with coexistent viable fetus detected by routine AFP screening
}

Measurement of maternal serum $\alpha$-fetoprotein (AFP) concentrations may soon become routine between 16 and 20 weeks of pregnancy as a screening test for fetal neural tube defects. ${ }^{1}$ Concentrations may also be raised in several other conditions, including threatened, inevitable, and missed abortion ${ }^{2}$ and various congenital abnormalities of the fetal gastrointestinal tract and other sites. ${ }^{3}$ We report a case in which a hydatidiform mole coexistent with a viable fetus was detected by routine maternal AFP screening.

\section{Case report}

A 29-year-old primigravid Caucasian patient was found at 16 weeks' gestation to have a grossly raised maternal serum AFP concentration of $2800 \mu \mathrm{g} / 1(90 \%$ confidence limits at 16 weeks $20-130 \mu \mathrm{g} / \mathrm{l})$. The antenatal course had been unremarkable but the uterine size was consistent with 18-20 weeks' gestation. Fetal movements were felt and there was no vagina bleeding. Ultrasound examination two weeks later showed a single live fetus (estimated gestation 18-19 weeks) compressed by gross proliferation of half of the placenta (figure). A number of echo-free zones in the placenta and multiple cysts of the ovaries were seen. The appearance was consistent with that of a hydatidiform mole coexistent with a live fetus. The amniotic fluid AFP concentration was normal at $8.5 \mathrm{mg} / \mathrm{l}$. After discussion with the patient pregnancy was terminated by giving intra-amniotic prostaglandin $F_{2} \alpha$. The placenta was grossly abnormal with the characteristic features of hydatidiform mole. The female fetus had no abnormality. The histological appearance of the placenta was consistent with hydatidiform mole. The postoperative course was unremarkable and plasma human chorionic gonadotrophin concentrations have been under 25 IU/l since six weeks after abortion.

\section{Comment}

Raised maternal serum AFP concentrations in hydatidiform mole are extremely uncommon, since the major source of maternal AFP is

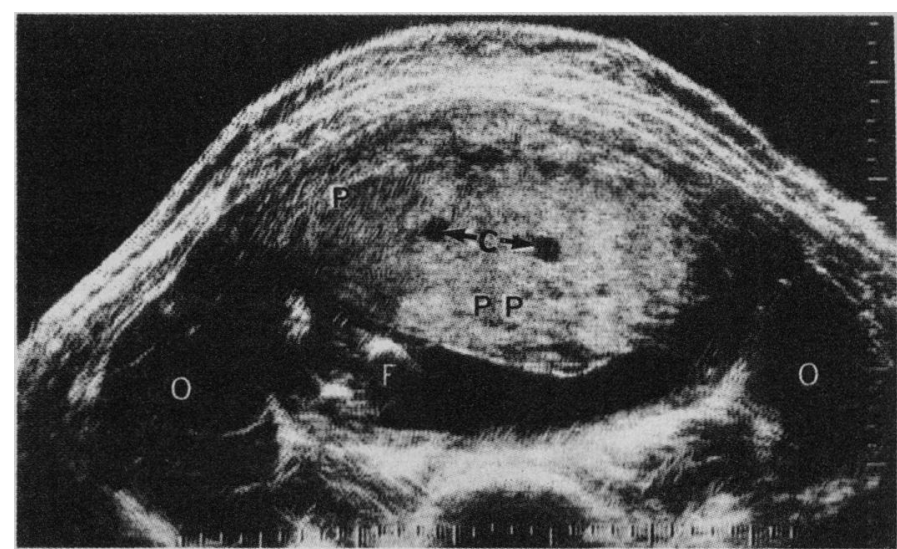

Transverse echogram of pelvis showing abnormal placental proliferation (PP) encroaching on fetus (F). Normal placenta (P) area is well delineated from abnormal placental proliferation with cystic areas (C). Both ovaries have multiple cysts $(\mathrm{O})$.

the fetal liver. ${ }^{4}$ Nevertheless, evidence of AFP synthesis by abnormal trophoblastic tissue has been reported. ${ }^{5}$ The normal amniotic fluid AFP concentration in the presence of a normal fetus when the maternal serum AFP concentration was grossly raised was an unexpected finding in our case. Although the reason for the raised maternal concentration is unclear there are two likely explanations. Firstly, the altered permeability of the molar tissue may allow increased diffusion of AFP into the maternal circulation. Secondly, abnormal synthesis of AFP by molar tissue cannot be excluded in this patient.

This case report not only adds yet another abnormality of pregnancy, albeit rare, that may be detected by routine AFP screening but also emphasises the mandatory complementary role of ultrasound. If ultrasound examination had not been performed, since the amniotic fluid AFP concentration was normal the gross abnormality would have been missed.

${ }^{1}$ Clarke PC, Gordon YB, Kitan MJ, Chard T, Letchworth AT. Screening for fetal neural tube defects by maternal plasma alphafetoprotein determination Br 7 Obstet Gynaecol 1977;84:568-73.

${ }^{2}$ Garoff L, Seppala M. Prediction of fetal outcome in threatened abortion by serum placental lactogen and alpha-fetoprotein. Am $\mathcal{F}$ Obstet Gynecol $1975 ; 121: 257-61$.

${ }^{3}$ Clarke PC, Gordon YB, Kitan MJ, Chard T, McNeal AD. Alphafetoprotein levels in pregnancies complicated by gastrointestinal abnormalities of the fetus. Br $\mathcal{F}$ Obstet Gynaecol 1977;84:285-9.

4 Gitlin D, Perricelli A, Gitlin GM. Synthesis of alpha-fetoprotein by liver, yolk sac and gastrointestinal tract of the human conceptus. Cancer Res 1972;32:979-82

5 Grudzinskas JG, Kitan MJ, Clarke PC. An extrafetal origin of alphafetoprotein. Lancet 1977; ii:1088.

(Accepted 7 February 1980)

Department of Obstetrics and Gynaecology, Royal North Shore Hospital of Sydney, St Leonards, NSW 2065, Australia

D H SMITH, MRCOG, MAUSTCOG, professorial registrar (now senior registrar, Royal Free Hospital, London)

R H PICKER, FAUSTCOG, DDU, obstetrician

D M SAUNDERS, FAUSTCOG, MRCOG, associate professor

$M$ SINOSICH, BSC, scientific officer

J G GRUDZINSKAS, FAUSTCOG, MRCOG, senior lecturer

\section{Addiction to Distalgesic (dextropropoxyphene)}

Distalgesic is a proprietary preparation containing dextropropoxyphene $32.5 \mathrm{mg}$ and paracetamol $325 \mathrm{mg}$ per tablet. It is widely prescribed for mild to moderately severe pain. Both components are effective analgesics by mouth. Dextropropoxyphene was introduced in 1957 as a substitute for codeine. Five other proprietary preparations containing dextropropoxyphene are now available in the United Kingdom. Dextropropoxyphene is similar in structure to methadone. It is a centrally acting drug without antipyretic or anti-inflammatory 
properties and is thought to increase the analgesic effect of peripherally acting drugs. Concern has been growing about the dangers of dextropropoxyphene as a cause of death in acute overdosage, particularly when it is taken with alcohol and other centrally acting drugs. ${ }^{1}$ Its potential for producing dependence has been widely reported in the United States. Recently addiction to Distalgesic has been reported in Britain. ${ }^{2}$ We report a further case here where withdrawal was successfully effected.

\section{Case report}

A 41-year-old woman with a history of multiple drug abuse in her teens began taking Distalgesic in 1976 to relieve pain after a hysterectomy. She continued to take it regularly since it relieved the chronic back pain and headache from which she also suffered. After several months of uninterrupted consumption she had developed tolerance to its effects. During three years she had gradually increased her consumption to 32 tablets daily. While taking Distalgesic she felt well, confident, and better able to cope with life. When she attempted to stop taking it she had withdrawal symptoms consisting of severe headache, nausea, tremulousness, drowsiness, shivering, and watering eyes. She was also bad tempered, irritable, and subject to overwhelming misery and a severe craving for the drug. She made many importunate demands for prescriptions from her general practitioner. This culminated in her forging a prescription in June 1978, for which she received two years' probation.

Haematological testing gave normal results except for a raised cell volume (110 fi). $\gamma$-Glutamyltransferase activity was also raised at $139 \mathrm{IU} / 1$ and the calcium concentration slightly depressed $(1.95 \mathrm{mmol} / 1(7.8 \mathrm{mg} / 100 \mathrm{ml})$ ). A liver biopsy performed shortly after admission showed some cloudy swelling of the hepatocytes and an increased amount of "wear and tear" pigment. The patient denied alcohol abuse. Treatment consisted in withdrawing Distalgesic and giving methadone on a reducing scale, starting with $5 \mathrm{mg}$ four times a day. Methadone was withdrawn completely within 10 days. While on it she had no withdrawal symptons. But on complete withdrawal of methadone she had low-grade symptoms of misery, nausea, headache, and slight tremulousness. When followed up as an outpatient she had not returned to taking Distalgesic and her symptoms were slowly abating.

\section{Comment}

Dextropropoxyphene is the psychoactive ingredient of several widely used analgesics (table). National Health Service prescriptions for these in 1975 totalled 74383 and had risen by about $20 \%$ a year

Formulae of proprietary drugs containing dextropropoxyphene

\begin{tabular}{lccc}
\hline & Dextropropoxyphene & Paracetamol & Aspirin \\
\hline Depronal SA & $150 \mathrm{mg}$ & - & - \\
Distalgesic & $32.5 \mathrm{mg}$ & $325 \mathrm{mg}$ & - \\
Dolasan & $100 \mathrm{mg}$ & - & $325 \mathrm{mg}$ \\
Doloxene & $65 \mathrm{mg}$ & - & $500 \mathrm{mg}$ \\
Napsalgesic & $50 \mathrm{mg}$ & - & - \\
SK-65 & $65 \mathrm{mg}$ & & \\
\hline
\end{tabular}

over the preceding three years. A survey of patients discharged from hospitals in a health district showed that 1 in every 38 patients was receiving the drug (AC Bower, unpublished communication, 1979). It is rapidly absorbed from the gastrointestinal tract and passes readily from the blood into body tissues. Dextropropoxyphene is structurally related to methadone and is similar in its onset and duration of action to codeine. It produces dependence of the morphine type. Initially it was thought to be a drug of low potential for abuse and relatively safe, and was introduced to compete with codeine as the analgesic of choice for chronic or recurrent mild-to-moderate pain. Dependence was first reported in 1963 in a 28-year-old-man who consumed $960 \mathrm{mg}$ of dextropropoxyphene daily. ${ }^{3}$ Two further cases of dependence were reported in 1966 and another in 1969.

Seemingly, prolonged administration of medications containing dextropropoxyphene leads to tolerance and dependence. Another danger is its ability to produce respiratory depression in relatively low doses. Controlled studies have failed to show that dextropropoxyphene is any more efficacious than paracetamol or aspirin alone. ${ }^{4}$ The use of drugs containing it should be reappraised in view of the hazards.

1 Whittington RM. Dextropropoxyphene (Distalgesic) overdosage in the West Midlands. Br Med $\mathcal{f} 1977 ;$ ii :172-3.

2 Whittington RM. Dextropropoxyphene addiction. Lancet 1979 ;ii:743-4.

3 Elson A, Domino EF. Dextropropoxyphene addiction: observations of a case. f $A M A$ 1963;183:482-5.
4 Hopkinson JH, Blatt G, Cooper M, et al. Effective pain relief: comparative results with acetaminophen in a new formulation, propoxyphene, napsylate-acetaminophen combination, and placebo. Current Therapeutic Research 1976;19:622-30.

(Accepted 8 February 1980)

Regional Addiction Treatment Unit, All Saints' Hospital, Birmingham B18 5SD

ROBERT WALL, MB, MRCPSYCH, senior registrar

SUSAN M J LINFORD, MB, registrar

M IFTIKHAR AKHTER, MB, MRCPSYCH, consultant psychiatrist

MIFTIKHAR AKHTER, MB, MRCPSYCH, consultant psychiatrist

\section{Megaloblastic anaemia due to vitamin $B_{12}$ malabsorption associated with long-term metformin treatment}

Metformin has been used extensively in treating maturity-onset diabetes. It has few side effects, but it inhibits active vitamin $\mathbf{B}_{12}$ absorption in the distal ileum. Annual serum vitamin $\mathbf{B}_{12}$ measurements are therefore advisable in patients on long-term treatment. ${ }^{12}$ So far no other case of vitamin $\mathbf{B}_{12}$-deficient megaloblastic anaemia due to metformin therapy has been reported.

\section{Case report}

In 1960 a 47-year-old woman gradually developed polyuria and polydipsia. Her height was $1.57 \mathrm{~m}$ and weight $88 \mathrm{~kg}$. Her initial $2 \frac{1}{2}$-hour postprandial venous blood glucose was $10 \cdot 1 \mathrm{mmol} / 1(182 \mathrm{mg} / 100 \mathrm{ml})$. She was put on a $4 \cdot 18 \mathrm{MJ}(1000 \mathrm{kcal})$ diet containing $100 \mathrm{~g}$ carbohydrate. Chlorpropamide $250 \mathrm{mg}$ daily was started after one year and within three years metformin $0.5 \mathrm{~g}$ twice daily was added because of persistent hyperglycaemia. She was not careful with her diet. When she was 54 her haemoglobin was $13.7 \mathrm{~g} / \mathrm{dl}$ with normal indices. One year later serum vitamin $B_{12}$ and serum folate concentrations were normal. When aged 58, after eight years of metformin therapy, she became clinically anaemic with lassitude and general debility. There were no neurological signs of posterior column disease or peripheral neuropathy. Her haemoglobin was $8.9 \mathrm{~g} / \mathrm{dl}$, her mean corpuscular volume (MCV) $106 \mathrm{fl}$ (normal 84-99), and her mean cell haemoglobin (MCH) $36 \mathrm{pg}$ (normal $30-35 \mathrm{pg}$ ). Serum concentrations were: bilirubin $164 \mu \mathrm{mol} / 1$ $(9.8 \mathrm{mg} / 100 \mathrm{ml}$ ) (normal 3.0-21.0 $\mu \mathrm{mol} / \mathrm{l}$ ), lactate dehydrogenase $680 \mathrm{WL}$ units (normal 220-440), alkaline phosphatase 4.0 KA units (normal), calcium $2.4 \mathrm{mmol} / 1(9.6 \mathrm{mg} / 100 \mathrm{ml})$, and phosphorus $1.2 \mathrm{mmol} / 1(3.7 \mathrm{mg})$ $100 \mathrm{ml}$ ). Serum vitamin $B_{12}$ was $60 \mathrm{ng} / 1$ (normal range 150-900) and serum folate $3 \cdot 1 \mu \mathrm{g} / \mathrm{l}$ (normal range $3 \cdot 5-24 \cdot 0$ ). Blood urea was normal.

A bone marrow aspirate showed a highly cellular pattern with all three cell lines present. The red and white cells were notably megaloblastic with predominance of the erythroid series. A modified combined Schilling test showed $6.2 \%$ of a test dose of ${ }^{58} \mathrm{Co}$-labelled vitamin $B_{12}$ excreted in 24 hours (normal range $10 \cdot 1-32 \cdot 1 \%$ ) and $4.8 \%$ of a test dose of ${ }^{57} \mathrm{Co}$-labelled vitamin

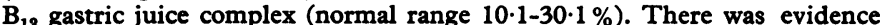
of gastric secretion of free hydrochloric acid (azuresin (Diagnex Blue) test). Concentration of serum gastrin was $65 \mathrm{ng} / \mathrm{l}$ (normal 9-150), serum iron $10 \mu \mathrm{mol} / 1(55.9 \mu \mathrm{g} / 100 \mathrm{ml}$ ) (normal 14-25 $\mu \mathrm{mol} / \mathrm{l})$, total iron-binding capacity $65 \mu \mathrm{mol} / 1$ (363 $\mu \mathrm{g} / 100 \mathrm{ml}$ ) (normal 45-72 $\mu \mathrm{mol} / \mathrm{l}$ ), and serum carotene $1 \mu \mathrm{mol} / 1(53.7 \mu \mathrm{g} / 100 \mathrm{ml}$ ) (normal). Barium studies showed some flocculation and clumping in the proximal ileum but insufficient to suggest a major malabsorption syndrome. There were no local lesions and the terminal ileum was normal. The fat content of a three-day collection of faeces was normal. Intrinsic factor antibody was absent. Treatment was with cyanocobalamin $1000 \mu \mathrm{g}$ by injection daily at first and subsequently monthly. Serum vitamin $B_{12}$ rose to over $1000 \mathrm{ng} / 1$ and haemoglobin to $13.9 \mathrm{~g} / \mathrm{dl}$, and MCV fell to $81 \mathrm{fl}$, and $\mathrm{MCH}$ to $28 \mathrm{pg}$. She died suddenly when aged 63, probably from myocardial infarction.

\section{Comment}

Side effects of metformin, apart from occasional initial nausea, are rare. Lactic acidosis is very unusual in correct clinical usage. ${ }^{3}$ We found that vitamin $B_{12}$ malabsorption as shown by a Schilling test was abnormal in $30 \%$ of patients who had been on the drug for a mean of four to five years. ${ }^{1}$ No patient in that series had actually become anaemic, although three patients had pathologically low serum vitamin $B_{12}$ concentrations and a fourth had a low normal concentration with macrocytosis. The patient reported here developed 